\title{
A digitális kor gyermekei
}

\section{Lénárd András}

Eötvös Loránd Tudományegyetem, Tanító- és Óvóképző Kar, Digitális Pedagógia Csoport

\begin{abstract}
A közoktatásban manapság egyre gyakrabban találkozunk azzal a megfogalmazással, miszerint a most iskolába lépő illetve az ott tanuló gyerekek sokkal nehezebben kezelhetők, mint az előző generáció. A tanulmány áttekinti az információs társadalom sajátosságait, majd a már közismert generációelméletek kritikáit fogalmazza meg. Bevezet egy új kifejezést is, mely a generációelméletek egyfajta veszélyére figyelmeztet: a digitális Pygmalion-effektust. Kitér a digitális kor gyermekeinek azon tulajdonságaira, melyek a megváltozott társadalmi háttérből és az információ mennyiségének és terjedési sebességének növekedéséből adódnak.

A leglényegesebb probléma azonban a tanitás-tanulás és a nevelés oldaláról mindenképpen az, hogy a különböző digitális generációhoz tartozó pedagógus és tanulók együttmüködése, közös munkája hogyan valósulhat meg az információs társadalomban. E kérdéskör szempontjainak felvillantása után a pedagógus megváltozott szerepkörének kérdéskörét elemzi és igyekszik eloszlatni azt a gyakran emlegetett félelmet, miszerint a digitális generáció előtt lebomlóban van az idősebb pedagógus-generációk tekintélye.
\end{abstract}

Kulcsszavak: digitális nemzedék, információs társadalom, hálózatosodás, multitasking, konnektivizmus

\section{Problémafelvetés: „Ezek a gyerekek mások...”}

A közoktatásban manapság egyre gyakrabban találkozunk azzal a megfogalmazással, miszerint a most iskolába lépő, illetve az ott tanuló gyerekek sokkal nehezebben kezelhetők, mint az előző generáció.

Ez mind nevelési, mind oktatási kérdésekben egyaránt megnyilvánul a pedagógusszakma képviselői szerint. Valójában nem új jelenséggel állunk szemben, hiszen mindenkor igaz volt, hogy a nevelést, oktatást végzők elégedetlenek a rájuk bízott gyermekek jellemzőivel. most azonban úgy tűnik, másról van szó. Nemcsak a pedagógusok, hanem az egész társadalom egyetért abban, hogy a most felnövekvő generáció speciális sajátosságokkal rendelkezik, ami miatt bizonyos nevelési eljárások nem annyira hatásosak, mint a korábbi években. Abban is egyetértés mutatkozik, hogy ezek a gyerekek bizonyos dolgokkal szemben más reakciókat tanúsítanak, mint a korábbi években. Érdemes alaposan megvizsgálni a digitális kor gyermekeit, s egy viszonylag széleskörü áttekintést tenni abból az okból, hogy feltérképezhessük, valóban léteznek-e bizonyos generációs jellemzők, és valóban az egész felnövekvő tanuló generációra jellemzőek-e ezek a sajátosságok.

\section{A háttér: az információs társadalom}

Az információs társadalom mint társadalmi berendezkedés többféle néven is szerepel a vonatkozó szakirodalmakban. Nevezzük tudástársadalomnak, tudásalapú társadalomnak, tudásiparnak (Machulp, 1962), illetve posztindusztriális társadalomnak is (Touraine,1988). Mi jellemző erre a speciális közegre, melyben a digitális kor gyermekei nevelődnek? Mint az elnevezések sokasága is mutatja, az egyik fő csomópont az in- 
A digitális kor gyermekei

formáció, a tudás megléte, illetve az ezzel kapcsolatos műveletek végzése a társadalom tagjai részéről. A tudás szerepe egyre inkább felértékelődik, s az egyik jellemzője lehet az információs társadalomnak az, hogy az emberek, a polgárok mindennapi tevékenységébe mind nagyobb szelet jut a tudással való foglalatosságnak (Sther, 2002). Touraine (1988) megfogalmazása szerint:

„A posztindusztriális társadalomba való átmenet akkor megy végbe, amikor az értékeket, szükségleteket és értelmezéseket megváltoztató szimbolikus javak előállítására irányuló befektetések jóval meghaladják a materiális javakét, vagy szolgáltatásokét."

Ennek az egyre erőteljesebben előtörő és felértékelődő információnak nagyon fontos közösség-, illetve társadalomszervező szerepe is van. Az információs társadalom társas formáció a társadalmi hálózatokkal, amelyek tulajdonképpen véghezviszik annak az elsődleges szerveződését mind az egyén, mind különféle csoportok, mind az egész társadalom szintjén (Van Dijk, 2006). Ha az összes megközelítést és definíciót megpróbáljuk egységes módon értelmezni, akkor azonnal szembetűnik, hogy a fő rendezőelv az információ megléte, az információval való bánásmód-műveletvégzés, az információ feldolgozása, illetve saját céljainkra való felhasználása. Ebből a szempontból a tudás is, mint információ jelenik meg.

\section{Generációelméletek}

Minden bizonnyal éppen az információ az, amelyiknek mennyisége, terjedésének sebessége speciális hatást gyakorol a felnövekvő generáció tagjaira. Valószínűleg, hogy ez a legfőbb oka annak, hogy sajátosságaik eltérnek az előző generációk sajátosságaitól. Mark Prensky híres cikke a digitális bennszülöttekről és digitális bevándorlókról kissé leegyszerűsítve ugyan, de jól megfogható jelelemzőit adja a felnövekvő generációknak, az ő szóhasználatában a digitális bennszülötteknek (Prensky, 2002.) Ezek közül csak azokat tárgyalnám részletesen, melyeknek kimondottan az információ terjedéséből, és mennyiségéből adódó szerepe van. A didaktikának mindenképpen számolnia kell a továbbiakban azzal, hogy a hagyományos lineáris tanulási modellek helyett ez a generáció képes arra, hogy párhuzamosan, vagy legalábbis párhuzamosnak látszó módon dolgozzon fel eltérő természetü információkat, gyakorlatilag egy időben. A problémát az adja, hogy a pedagógusok zömét adó digitális bevándorlók még jórészt a lineáris algoritmusokat tanulták, sajátították el, és alkalmazzák a tanítás során. A digitális bennszülöttek gondolkodásmódjára nem csak a párhuzamosság, hanem a lineáris, egymásból következő elemeket felvonultató láncolat helyett, az úgynevezett hipertextes gondolkodás is jellemző. Mit értünk ez alatt? Ahogyan az internet világában a hipertextes felületeket ugrópontok, linkek tarkítják, és ezek egy más dokumentumra, vagy az adott dokumentum egy másik pontjára mutatnak, a gyerekek gondolkodásában is léteznek ilyen fajta linkszerü momentumok. Ezek a „linkek” lehetnek gondolatelemek, egy-egy új információ, egy ábra egy kép, de lehetnek az adott szituációban előtörő emléknyomok is, illetve már meglévő tapasztalatok. Ezek a gondolati linkek ezután a tanuló gondolkodását egy más természetű elemre irányítják. Ezáltal egy olyan átkapcsolódás jön létre a gondolatmenetében, melyet a külső szemlélő nem igazán tud követni, vagy nem minden esetben lát indokoltnak. Nagyon sokszor a napi gyakorlatban ezt figyelmetlenségnek, mással foglalkozásnak, csapongásnak érzik a pedagógusok. A hipertextes gondolkodás legföbb nehézsége abban jelentkezik, hogy a gondolatmenet a külső szemlélő számára nem egyértelmü, nem tudjuk, hogy ezek a „linkek” hogyan keletkeztek, milyen irányba hatnak, és nem utolsó sorban ezek messze nem egységesek az osztály összes tanulójánál, hanem nagyon is az egyénre jellemző- 
ek. Többek között a hipertextes gondolkodás és a gyors információfeldolgozás, illetve a párhuzamos adatfeldolgozási mód a felelős azért, hogy a hagyományos, jól bevált pedagógiai algoritmusok sokszor nem müködőképesek, vagy legalábbis nem olyan módon müködnek, mint az eddigiekben. Emiatt a többéves óravázlatok abban a formában már nyilvánvalóan nem használhatók fel, ahogyan eddig. Sokkal kevésbé tudjuk kontrollálni, követni, s nem utolsó sorban egységesíteni a tanulók gondolkodását. Természetesen ez nem is lehetett célunk az eddigiekben sem, de mostanában egyre gyakrabban tapasztaljuk azt, hogy egy osztálynyi tanulónak adott problémát szinte az osztálylétszámnak megfelelő számú eljárásban, egyéni algoritmussal, sajátos utakat bejárva oldanak meg a tanulók. Ez rendkívül örvendetes és a pedagógiának mindenképpen számolnia kell vele, azonban nagyon sokszor a hagyományos oktatás kereteihez szokott és attól eltérni nem akaró pedagógusok számára ez rendkívüli problémákat jelenthet. Prensky a digitális bennszülöttek eltérő gondolkodásmódja okaként a neuroplaszticitás jelenségét írja le, mely az angolszász terminológiát használva az agy egyfajta újradrótozását jelenti, vagyis a digitális bennszülöttek agyműködésének megváltozását megnövekvő mennyiségủ és növekvő sebességgel áramló információ hatására.

Találkozhatunk a szakirodalomban egy másik, Prenskyénél ismertebb, a laikus szóhasználatba is bevonuló generációelmélettel. Howe és Strauss generációelmélete már árnyaltabban fogalmaz. Nem két nagy generációt ír le, hanem a születési évtől függően jelenleg öt generációval számol a veteránoktól kezdődően egészen az 1996-tól született Z-generációs gyermekekig (Howe és Strauss, 2000) Ezt a generációelméletet nagyon sokszor idézik, és elég népszerű valószínűleg azért, mert egészen precízen, a születési évszámoktól határolva azonosítható az egyes gyermekek generációja, valamint a generációkhoz jól leírható, egyértelmű jellemzőkkel alkotott egyfajta generációs profilokat mellékeltek a szerzők. Ha áttekintjük a generációs jellemzőket, szembetűnik, hogy az egyedüli rendezőelv, amely ezeket a jellemzőket szervezi az, hogy a technikai eszközökkel, illetve internet-hozzáféréssel ellátottság szempontjából melyik korban születtek (1. ábra).

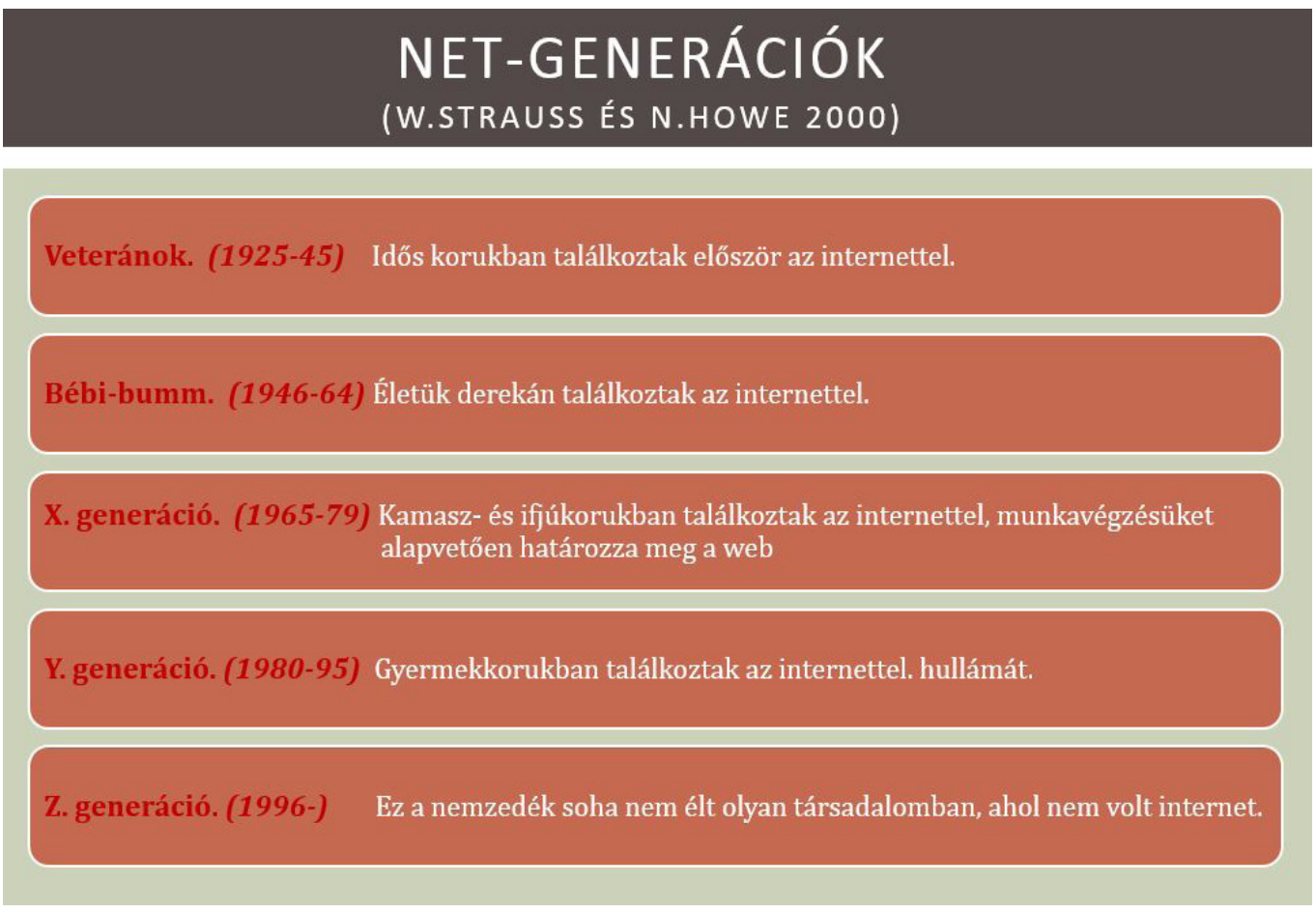

1. ábra: A Net-generációk életkori szakaszai Howe és Strauss Generáció-elméletében. 
Az 1996-tól született Z-generáció legfőbb jellemzője például az, hogy nem éltek ezek a gyermekek még olyan társadalomban, ahol nem volt internet. Az Y-generáció gyermekkorában találkozott internettel, míg az X-generáció kamasz- és ifjúkorában.

\section{A generációelméletek kritikája, kísérletek finomításukra}

Már ez a fajta kategorizálás is elővetítni ennek a generációelméletnek a legfőbb hátrányát, ugyanis az, hogy egy ember mikor találkozott az internettel, nemcsak az életkortól függ, hanem nagyon is függ a gazdasági, szociokulturális háttértől, földrajzi elhelyezkedéstől, illetve egy adott országon belül egy adott térség fejlettségétől stb. Éppen ezért ez a generációelmélet jelenleg puhulni látszik, mivel túl merevnek tűnik ez a kizárólag technológiai szempontból történő kategorizálás. Egyértelműen kitűnik, hogy bár egységes kategóriaként tekintenek a generációelmélet szerzői az egyes csoportokra, mégsem alkotnak homogén csoportot az adott évszámhatárok között született gyermekek. Éppen ezen okból kifolyólag a túlságosan kategorizált generációelméletek egyfajta ellentmondásként jelentkeznek a pedagógiában. A Netgeneráció 2010 felmérés kapcsán már jóval árnyaltabb kép körvonalazódik a Prensky által vázolt modell egy generáción belül jól megkülönböztethető alcsoportjaira történő tagolásával (FehérHornyák, 2011). Az is érdekes megfigyelés és némileg ellentmond a várakozásoknak, hogy ezek a Prensky által digitális bennszülötteknek tekintett gyerekek sem rendelkeznek automatikusan, és az egész generációra jellemző módon annyira fejlett módon azokkal a digitális kompetenciákkal, melyek előfeltételei e generáció létezésének illetve boldogulásának.

Z. Karvalics (2013) szintén elveti az egyszerü és spontán „beleszületés” elméletét. A törzsi beavatási szertartásokra is asszociálva úgy gondolja, hogy a társadalom segítsége, a kedvező környezet is szükséges ahhoz, hogy a digitális nemzedék megfelelhessen azoknak a kihívásoknak, melyeket az információs társadalom megkíván. Még szemléletesebbnek érzem azonban a kifejezés kiterjesztését egy másik hasonlattal:

„Mind a magyarban, mind az angolban a beavatás (initiation) hordoz egy másik, szintén nagyon elterjedt jelentést: textilneműk festékkel, impregnáló anyagokkal való átitatását a későbbi felhasználás előtt, valamilyen tulajdonságot kialakító vagy megerősítő szándékkal. Egyáltalán nem képzavar arra (is) asszociálni akár, hogy a fiatal nemzedék a textil, a digitális kultúra pedig az a festékanyag, amelybe belemerül, mielőtt megkezdené valódi küldetésének végrehajtását."

(Karvalics, 2013. 23)

\section{A digitális Pygmailon-effektus}

A reformpedagógiai törekvések, miszerint a tanulókra nem egy egységes, jól leírható jellemzőkkel rendelkező lényként tekintünk, hanem egy egyszeri és megismételhetetlen egyéni sajátosságokkal rendelkező gyermekre, éppen a jól behatárolt generációs jellemzők miatt megtorpanni látszik. Sőt, a generációelméletek által létrejön egy egyfajta új, kategorizált és egységesebb gyermekkép. Ez mindenképpen ellentmondásnak látszik, mi több, veszélyeket is rejt magában. Ha úgy tetszik, egyfajta digitális Pygmalion-effektusként a pedagógusok már a kész generációs jellemzők birtokában kerülnek kapcsolatba a tanulókkal, mely jellemzők esetenként előfeltevésekként befolyásolják az egyes tanulók jellemzőinek megfigyelését, egyéni sajátosságaiknak figyelembe vételét. Ez az előfeltevés egyéni vonásaiknak feltérképezését is rossz irányba viheti, illetve egyoldalúan befolyásolhatja. Elképzelhető, hogy a továbbiakban ezen előfeltevések miatt, illetve az ezekhez társuló pedagógusreakciók miatt is létrejöhetnek 
olyan viselkedésminták és reagálások, melyeket az adott generációnak tulajdonítottunk. A kutatások a továbbiakban jóval árnyaltabb képet mutatnak, egyre inkább számolnak a regionális, illetve szociális sajátosságokkal, s legfőképpen a meglévő előzetes tudással, egyéni programokkal, gondolkodási struktúrákkal.

\section{A digitális kor gyermekei és a tanulás}

Ezek közül említésre méltó például Komenczi Bertalan mezovilág modellje, amely a nyitott tanulási környezet jelentőségét hangsúlyozza, mely egyfajta hídként szerepel a világmindenség össze információ halmaza, és a gyerekek saját belső világa - az ő megfogalmazásában - mikrovilágai között (Komenczi, 2009). Nagyon lényeges sajátossága az elméletnek, hogy ezekre a mikrovilágokra nem, mint üres, fehér lapokra tekint, hanem a konstruktív pedagógia szellemében nagy jelentőséget tulajdonít a tudásépítés szempontjából a meglévő tapasztalatoknak, a korábbi tudásnak, az eltérő tanulási stílusoknak, az eltérő kulturális háttereknek, világszemléleteknek stb. (2. ábra).

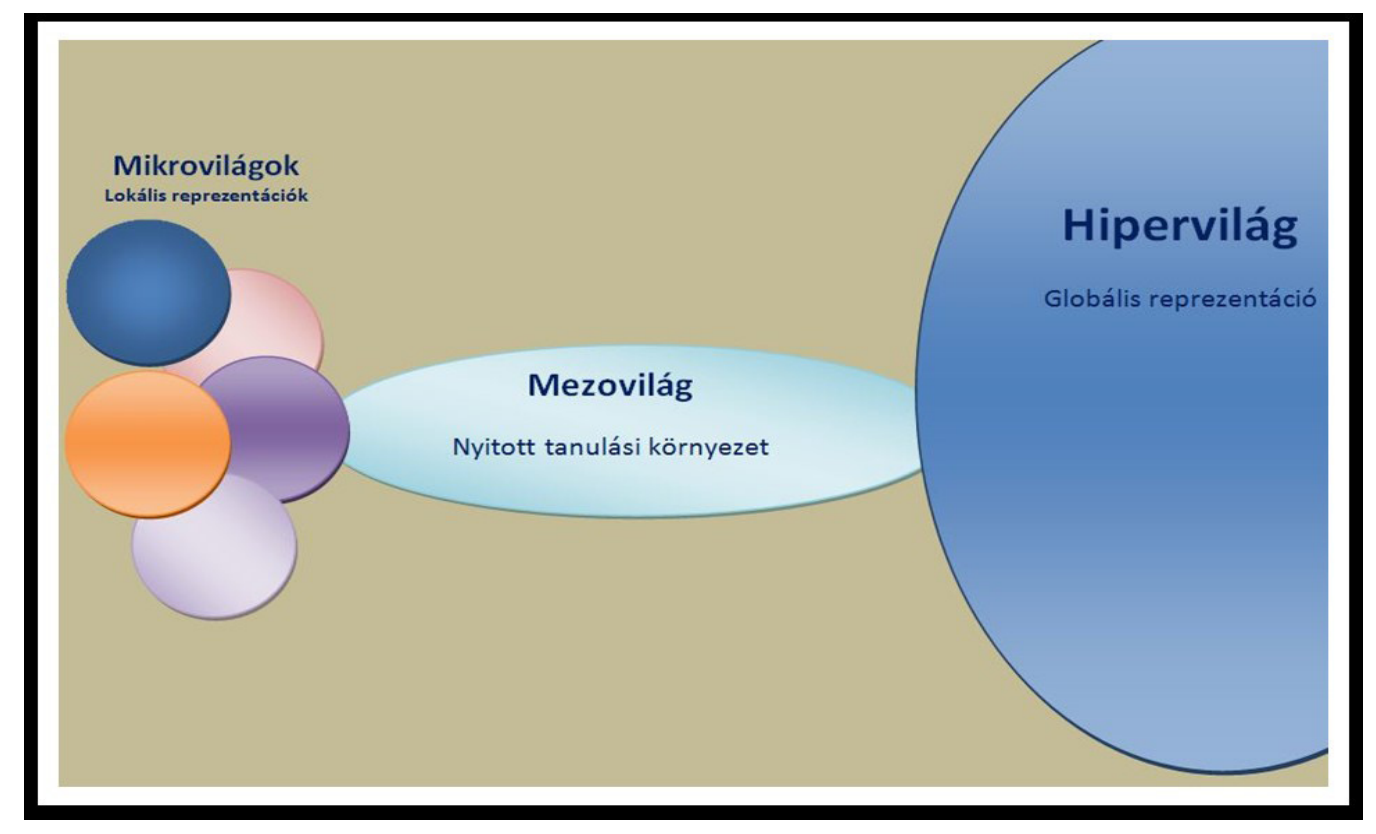

2. ábra: Komenczi Bertalan Mezovilág-elméletének vázlata

Ez a modell például sokkal inkább tükrözi a digitális korban megváltozott tanuláselméletek letisztultabb és az egyéni sajátosságokat is figyelembe vevő vonulatát, melyek erős ellenpontként hatnak a sokszor leegyszerüsítő generációelméletekkel szemben. Ezen elméletek azonban a laikus pedagógiai környezetben igen erősen tartják magukat azáltal, hogy sokszor jó fogódzót jelentenek a részletesen leírt és tipizált tulajdonságok a laikusok számára. Éppen ezért Howe és Strauss generációelmélete igen népszerü, sokat idézett, hivatkozott elmélet manapság is anélkül, hogy sokszor a generációelméletre hivatkozó, vagy azt alkalmazók tisztában lennének annak mélyebb rétegeivel.

\section{Néhány, a digitális kor által indukált változás a gyermekek tevékenységeiben}

A továbbiakban érdemes áttekinteni néhány föbb csomópontként azokat a jellemzőket, melyekkel változatos formában ugyan, de minden olyan pedagógus találkozik, 
vagy találkozni fog, aki a felnövekvő, digitális kor gyermekeiként is nevezett tanulókat fogja tanítani. Az első a gyors és sokrétű ingerekhez való hozzászokást, illetve az ingereknek az alkalmazását jelenti. Ezek a gyermekek sokkal inkább képesek a megosztott figyelemre, mint az előző generációk, azonban hiba lenne azt gondolni, hogy ez a megosztott figyelem több párhuzamos és egyben elmélyült gondolkodási tevékenységet tesz lehetővé minden tanuló esetén. Meg kell ismerkednünk - hiszen találkozni fogunk vele a tanítás során - egy új jelenséggel, az információs türelmetlenséggel. Nyilvánvaló, hogy a gyors és élénk információhoz szokott gyerekek egyfajta türelmetlenséget fognak érezni abban az esetben, hogyha az információk mégsem érkeznek az elvárt sebességgel, illetve nem lesznek annyira élénkek, mint amennyire ők szeretnék. Példának okáért a hagyományos nyomtatott szöveg semmiképpen nem tekinthető élénk információnak és az olvasás, mint tevékenység semmiképpen nem gyors információ-szerzés. Érdekes megfigyelés az is, hogy annak ellenére, hogy hagyományos nyomtatott szövegeket dolgoznak fel a gyerekek, mégsem ugyanaz az agyi tevékenység zajlik minden esetben, mint egy más generációbeli, vagy internettel, számítógéppel csak ritkán kapcsolatba kerülő alanyé. Kimutatták, hogy a gyakorlott, illetve az alkalmi (vagy teljesen hárító) internet-, illetve számítógép-használók esetében más agyi területek aktívak olvasás közben (Small és Vorgan, 2008). Érdekes módon az alkalomszerü internethasználók esetében az olvasás, illetve webböngészés közbeni agyi tevékenységek közel hasonló képet mutattak, addig a gyakorlott internet-felhasználók esetében a webböngészés sokkal nagyobb agyi aktivitást váltott ki, mint a hagyományos szövegolvasás. Ez a jelenség lehet a magyarázata többek között annak is, hogy a mai iskolai gyakorlatban a hosszabb és akciókkal nem túlságosan tarkított szövegek olvasása nehézséget okoz a tanulók számára. Többek között ez vezetett oda, hogy mindenképpen felül kell vizsgálnunk azokat az olvasmányokat, regényeket, amelyeket akár kötelező olvasmányként, akár házi olvasmányként, akár közös feldolgozásban a gyerekek kezébe adunk. Szinte minden irodalmat tanító tanár, vagy tanító találkozott azzal a jelenséggel, hogy azok az irodalmi források, melyek évtizedeken keresztül jó feldolgozhatók voltak az iskolai gyakorlatban, mára már nem érik el azt a hatást, töltik be azt a szerepet, nem bűvölik el ugyanúgy a gyerekeket, mint eddig. Többnyire ez a gyakorlatban úgy nyilvánul meg, hogy ezt a gyerekek unalmasnak titulálják, és sokszor nem is tudják végigolvasni. llyenkor természetesen kézenfekvő a gyerekeket okolni azért, hogy ezeket a régi, értékes irodalmi forrásokat már nem szeretik. A háttérben azonban nem megátalkodottság, vagy az érdeklődés teljes hiánya áll, hanem az előző megfigyelésből is adódó egyéb ok, történetesen az, hogy ezek a szövegek már nem tartalmaznak megfelelő információt, nem élénkek, nem hatnak több érzékszervre egy időben, nem tartalmaznak ábrákat, animációkat, sokkal inkább statikusak, mint például egy weboldal. Ezáltal az általuk közvetített ingermennyiség jóval kevesebb, mint amit az ingerfalóknak is nevezett mai gyermekek megkívánnának. Ebből adódóan a szöveg unalmas lesz számukra, fellép az információs türelmetlensége jelensége.

Ugyancsak jellemző agyi működés a több feladat szimultán, illetve időosztásos módon történő feldolgozása. Ezt a tevékenységet az informatikából kölcsönvett multitasking kifejezéssel élve (Ollé, Papp-Danka, Lévai, Tóth Mózer és Virányi, 2013) egyfajta digitális korra jellemző gondolkodási struktúraként is értelmezhetjük. A hagyományos szekvenciális gondolkodás bizonyos pontokon szimultánná válik, illetve a tanuló gyors egymásutániságában végez el eltérő feladatrészleteket, melyek utána egésszé állnak össze, és a külső szemlélő számára úgy tűnhet, hogy párhuzamosan végezte azokat. Ebböl a szempontból tehát érdemes különbséget tenni a szimultán 
és multitasking gondolkodás között. A legtöbbször a szimultánnak tartott gondolkodási struktúra egyfajta időosztásos eljárással, gyors egymásutánban tulajdonképpen apró, váltakozó lineáris szakaszokként jelentkezik.

Laikus vélekedések szerint talán a legerősebb generációs jellemző a közösségi hálók térnyerésével a közösségben-hálózatban történő lét, gondolkodás, szórakozás, tanulás. Egyik megnevezése is innen ered a generációnak, az „always online” azaz a folyamatos online készenlétben lévő gyermekek generációja. A hálózati létforma számos, itt most nem tárgyalt rengeteg jellemzője közül érdekes módon a tanulásban nem nyilvánul meg automatikusan és szükségszerüen mindegyik. Vagyis a hálózatosodás nem jelentkezik automatikusan a tanulási tevékenységekben (Fehér és Hornyák, 2011). A közösségszervezésben azonban hatalmas ereje van még akkor is, ha az online közösségek jellemzői több ponton eltérnek a hagyományos közösség-értelmezésektől.

A konnektivizmus, melyet tekinthetünk akár Web 2.0 tanuláselméletének is, tulajdonképpen magából a hálózatosodásból vezeti le a tanulásszervezés új paradigmáját, mely lényege nagyon leegyszerüsítve az, hogy a tudásunkat lényegében kapcsolatok felépítésével, felépített hálóban, tudásmegosztással szerezhetjük (Kulcsár, 2003). Napjainkban a konnektivizmus, mint tanuláselmélet viták kereszttüzében áll, hívei az új tanuláselméletként tekintenek rá, mint a perszonalizált információ megjelenési formájára, s jóslataikban a Web 3.0 teles értékű tanuláselmélete lesz, mint a mindenhol jelenlévő tudás felhője (Turcsányi-Szabó, 2013). Ellenzői, illetve az óvatos elemzők szerint jelen pillanatban még nem tekinthető tanuláselméletnek, hiszen elsősorban magának a tanulásnak a folyamatát írja le, hanem a tudás szervezésének a módját, melyből önmagában még nem következik az, hogy az egyes felhasználók ezt hogyan és milyen módon építik be egyéni tudásuk rendszerébe. A konnektivizmus létjogosultságát minden bizonnyal az elkövetkező évek fogják igazolni, vagy elvetni.

\section{A digitális kor gyermekeinek kapcsolata az idősebb generációkkal}

A generációelméletek alkalmazásakor nemegyszer erőltetett szembeállításra kerül a jelenleg felnövő digitális kor gyermekeinek generációja és az úgymond „régi” vagy digitális bevándorló generáció. Prensky elméletében kissé kisarkítva, tulajdonképpen meg is ütközik a két generáció jellemzőit tekintve, Strauss és Howe generációelméletében pedig elkülönítve, különálló kategóriaként vannak jelen a veteránok és a bébi-boom generációja. Emiatt sokan generációs szakadékról beszélnek, egészen olyan leegyszerüsített módon megközelítve ezt a kérdést, hogy a digitális bennszülötteket nem értik a digitális bevándorlók, másképp gondolkodnak, és ezáltal a digitális bevándorlók tulajdonképpen alkalmatlanok a digitális bennszülöttek tanítására. Ez a megközelítés nyilvánvalóan túlzás, az azonban mindenképpen igaz, hogy a hagyományos módon az utóbbi évtizedek alatt megszokott pedagógiai eszköztár alkalmazásával az eddig használt és minden bizonnyal jól bevált algoritmusok segítségével, rugalmatlanul valóban nem érhetünk célt a digitális kor gyermekeinek tanítása és nevelése során. Mindenképpen változásra van szükség mindkét generáció részéről. A két generáció egymás mellett élése, közös alkotómunkája azonban egyáltalán nem reménytelen feladat, éppen Prensky adja egy jó példáját annak, hogy egy program fejlesztésénél sikerült a digitális bennszülötteknek és digitális bevándorlóknak olyan hatékonyan együttmüködni, hogy mind a két generáció sikeresen alkalmazta azokat az erősségeket, mely a saját generációjára jellemző volt, és sokat profitált azokból a pozitívumokból, amelyek a másik generációra voltak jellemzőek (Prensky im.), A kívánatos mindenképpen az 
A digitális kor gyermekei

lenne, hogy a továbbiakban a különböző szituációkban ez az elv érvényesüljön. Vagyis egy problémamegoldás során mindenki azokat az összetevőket adja a folyamathoz, amelyek az ő sajátosságaiból adódnak.

\section{A digitális kor pedagógusának tekintélye}

Ez a látszólagos vagy valós szembenállás azonban mindenképpen felvet egy olyan problémát is, amely a pedagógus tevékenységével, tekintélyével, sőt néha a létjogosultságával kapcsolatos. Vajon nem csorbul-e a pedagógusok tekintélye azáltal, hogy bizonyos szituációkban egyértelműen lassabb reakciókra képesek, másképpen dolgoznak fel információkat, illetve nem járatosak annyira abban a digitális közegben, melyet a most felnövekvő gyermekek már természetes életterüknek tekintenek. $\mathrm{Az}$ egészen bizonyos, hogy a hagyományos pedagógusszerep változóban van, azonban messze nincs arról szó, hogy a pedagógusokra kevésbé lenne szükség, netán feleslegessé válnának. A tevékenységének súlypontjai azonban áttevődnek máshová, és változni kénytelenek. A most iskolába kerülő, illetve iskolába járó generáció aktivitását tekintve sokkal meghatározóbb abból a szempontból, hogy az internetet passzívan szemlélő tartalomfogyasztókból aktív felhasználókká váltak, tulajdonképpen tartalomlétrehozókká és -megosztókká. Ez az aktivitás a pedagógusgeneráció nem minden rétegére jellemző. Ugyanúgy hiba lenne a pedagógustársadalmat digitális kompetenciák szempontjából egységes egésznek tekinteni, mint a digitális bennszülöttek generációját. A digitális bevándorlók, bármennyire is sokan vélik ezt, nem ismerve pontosan Prensky elméletét, nem utasítják el kategorikusan a digitális kor technikai és technológiai vívmányait. A legtöbben egyértelműen törekszenek azok megismerésére, s zömük azok használatára. Csak a megismerés-megtanulás módja hagyományos, leginkább kézikönyvekböl, tanfolyamokon szeretnék megtanulni, és a gyakorlati alkalmazás is alapos mérlegelés után történik. E folyamatot a sok megtorpanás, sokszor bizonytalanság is jellemezheti, más esetekben szinte teljesen problémamentes és gördülékeny. Ne felejtsük el, hogy a digitális bevándorlóknak legtöbbször nem áll rendelkezésükre saját, személyes példa arra vonatkozóan, hogyan működnek a tanulási folyamatban az IKT-eszközök. Mégis nekik kell megmutatni és megtanítani az alkalmazásukat egy ebből a szempontból helyzeti előnyben lévő generációnak. Egy részük továbbra is egyértelmúen passzív tartalomfogyasztóként van jelen az online világban. Látható elmozdulás a pedagógusok részéről, azonban ez korántsem olyan kifejezett és legföképpen nem olyan gyors, mint a tanulók reagálása. A legnagyobb változás talán abból a szempontból következett be, hogy a pedagógus megszűnt a tudás egyedüli birtokosának illetve forrásának lenni. Egyre gyakrabban tapasztalhatjuk, hogy az eltérő szituációkban, eltérő forrásokból merített információk behatolnak az iskolákba is, és a tankönyv, illetve a pedagógus magyarázata által közvetített egyetlen megközelítést sokszor más megvilágításba helyezik. Ez azonban örvendetes tény és a pedagógiának ezzel mindenképpen számolnia kell. Úgy gondolom, nem jelent tekintélyvesztést a pedagógus részéről az, hogyha bizonyos információkról ő is a gyerekektől értesül. Nem elhanyagolható azonban a pedagógus szerepe abból a szempontból, hogy a gyerekek által szerzett, hallott, kapott információk hitelessége sokszor nem egyértelmü. Nyilvánvaló, hogy a pedagógus sem döntheti el azonnal egy sokszor általa is éppen akkor először hallott információról, hogy megfelel-e a valóságnak, azonban mindenképpen mutathat olyan stratégiákat, illetve olyan eljárásokat, amelyek segítenek a tanulóknak abban, hogy meggyőződhessenek arról, hogy a más forrásokban, leginkább interneten talált információk valóban hitelesek-e. Nem szükséges a peda- 
gógusnak egy adott témából minden fellelhető információt ismernie, azonban példát mutathat azzal, hogy bizonyos módon ezeket megpróbálja szűrni, igyekszik például több forrásból meggyőződni annak hitelességéről, vagy mutathat a tanulók számára olyan mértékadó webes forrásokat, melyek önmagukban is jelenthetnek némi garanciát az ott fellelhető tudás minőségére. Éppen ezért elmondhatjuk, hogy az idősebb korosztály vonatkoztatási pont lehet az online térben. Ez nagyon fontos tény abból a szempontból, hogy a pedagógusok, illetve a gyerekekkel kapcsolatba kerülő felnőttek nem érzik, nem érezhetik magukat feleslegesnek. Nem tekintik magukat csekélyebb tudásúnak, és nagyon lényeges, hogy a pedagógusok generációja is megtalálja a helyét ebben az online környezetben, és bizonyos változások után, de mégis fontos szerephez jutnak a továbbiakban is a digitális kor gyermekeinek nevelésében. Számos példa mutatja, hogy az idősebb generációk tagjai példák, sőt példaképek lehetnek a digitális kor gyermekeinek számára akkor is, hogyha például technikai vonatkozások terén nem alkalmazzák olyan gördülékenyen a digitális kor vívmányait. Ez azonban ma már nem is minden esetben a hagyományos módon tekintett követelmény. Mindannyian, IKT-t alkalmazó pedagógusok valljuk, hogy a technikai vonatkozások terén már korántsem várható el a megingathatatlan és gördülékeny és teljesen hibamentes IKT-alkalmazás sem a pedagógusok, sem a gyerekek részéről, gyakran ütközünk „zátonyokba" (Nádori-Prievara, 2000). Sokszor tapasztalhatjuk, hogy egy program nem a megfelelő módon müködik, bizonyos funkciói megváltoztak, bizonyos hardverelemek müködésében összeférhetetlenség lép fel. Ez a technikai sokszínüség magával hordozza azt, hogy például a digitális alkalmazások sem olyan gördülékenyen müködnek, mint a hagyományos oktatástechnológiai eszközök. Ez a gördülékenység, bár a köztudatban nem ez él, nem automatikus és kizárólagos a gyermekek számára sem.

Nem különíthetők azonban el a két (vagy más megfogalmazások szerint, több) generáció céljai egymástól még akkor sem, ha digitális kompetenciáik eltérőek. A pedagógusoknak még akkor is óriási szerepük van és lesz abban a „beavatási” tevékenységben (Z. Karvalics, 2013), mely során kialakulnak a digitális kor gyermekeinek digitális kompetenciái, átjárja a „digitális festék a digitális bennszülöttek szövetét”. $E$ folyamat talán úgy is segíthető, ha mi magunk nem minden esetben rendelkezünk e kompetenciák magasabb szintjével. A változásokra kész, a gyerekek sajátosságai figyelembe vevő, és legfőképpen a tanítványaiért felelősséget érző (digitális bevándorló) pedagógus sokat tehet a digitális szakadék betemetéséért.

\section{Irodalom}

Bessenyei István (2010): A digitális bennszülöttek új tudása és az iskola. Oktatás-Informatika, 2010 2. 1-2. szám, 24-31.

Fehér Péter-Hornyák Judit (2011): 8 óra pihenés, 8 óra szórakozás, avagy a Netgeneráció 2010 kutatás tapasztalatai. In: Ollé János (szerk.) III. Oktatás Informatikai Konferencia Tanulmánykötet. ELTE Eötvös Kiadó, Budapest, 101-110.

Howe, N. and Strauss, W. (2000): Millennials Rising: The Next Great Generation. Knopf Doubleday Publishing Group.

Komenczi Bertalan (2009): Elektronikus tanulási környezetek. Gondolat Kiadó, Budapest.

Komenczi Bertalan (2009): Információ, ember és társadalom. Líceum Kiadó, Eger.

Kulcsár Zsolt (2008): XYZ generáció és a 4 tanuláselmélet. http://www.crescendo.hu/ 2008/11/2/az-integrativ-e-learning-fele-v2 (Utolsó letöltés: 2014. október 10.)

Machlup, F. (1962): The Production and Distribution of Knowledge in the United States. Princeton University Press, Princeton.

Nádori Gergely és Prievara Tibor (2000): Kis nagy IKT könyv http://tanarblog.hu/attachments/1979_ kisnagyiktkonyv.pdf (Utolsó letöltés: 2014. október 10.) 
Ollé János, Papp-Danka Adrienn, Lévai Dóra, Tóth-Mózer Szilvia és Virányi Anita (2013): Oktatásinformatikai módszerek. Tanítás és tanulás az információs társadalomban. Eötvös Könyvkiadó, Budapest.

Prensky, M.(2001): Digital Natives, Digital Immigrants. Part 1-2. 2001/10. On the Horizon, NCB University Press, 9, No. 5.

Small, G. and Vorgan, G. (2008): IBrain. Surviving the Technological Alteration of the Modern Mind. Harper Collins, New York.

Stehr N. (2002): A World Made of Knowledge. Lecture at the Conference "New Knowledge and New Consciousness in the Era of the Knowledge Society", Budapest, January 31st 2002.

Szabados Sándor (2009): Digitális bennszülöttek. Oktatás-Informatika, 2009 1, 19-24.

Touraine, A. (1988): Return of the Actor. University of Minnesota Press, Minneapolis.

Turcsányi-Szabó Márta (2013): A tanulási tér kiterjesztése - technológia és módszertan sajátos összefonódásai. http://videotorium.hu/hu/recordings/details/7620,A_tanulasi_ter_ kiterjesztese_technologia_es_modszertan_sajatos_osszefonodasai (Utolsó letöltés: $\overline{201 \overline{4}}$. október 10.)

Van Dijk, J. (2006): The Network Society. Sage, London.

Z. Karvalics László (2013): Mangalány mondja: közeledik a „digitális beavatottak” ideje. In: Lévai Dóra (szerk.) Digitális nemzedék konferencia 2013. Konferenciakötet. http:// digitalisnemzedek.hu/wp-content/uploads/2013/03/digitalisnemzedek-konferencia-2013. pdf 19-23.o. (Utolsó letöltés dátuma: 2014. 10. 20.) 